\title{
PIEZOMETRIC OBSERVATIONS OF WATER PRESSURE AT THE BED OF SWISS GLAGIERS
}

\author{
By H. Röthlisberger, A. Iken, and U. Spring
}

(Versuchsanstalt für Wasserbau, Hydrologie und Glaziologie an der Eidgenossischen Technischen Hochschule Zürich, CH-8og2 Zürich, Switzerland)

Abstract. A technique for drilling deep holes with a hot-water jet has been developed in recent years at our institute (Iken and others, [1977]). The holes have served to investigate the water pressure at the bed of various Swiss glaciers since i973. Drainage occurred naturally in rare cases when the drill reached the bed, but more often it was necessary to use explosives first, probably because the drill was stopped short of the bottom of the glacier by rock inclusions in the ice. In order to record piezometric water pressure over an extended period of time it was necessary that water was draining fairly continuously into the hole, otherwise the water level dropped eventually to a great depth when the weather turned cold, whereupon the holes closed off. By suddenly shutting off the water supply to a hole and observing the lowering of the water level with time some information on the channel characteristics has been obtained. In many cases there was little change of level, indicating that such a hole gives almost the true pressure head of the subglacial drainage system.

Our efforts have so far been concentrated on flat tongues of fair size over $100 \mathrm{~m}$ thick, the distance from the uppermost hole to the terminus ranging from about $\mathrm{I}$ to $4.5 \mathrm{~km}$. The main characteristic of the water pressure is a very large diurnal variation of the order of $100 \mathrm{~m}$ and more. The mean pressure generally rises and falls in times of high and low water supply, respectively, but re-adjusts to approximately the original level within a few days. Mean levels are higher early in the melt season than later, and the amplitude of the diurnal variation has a tendency to increase with time, but also shows strong short-term modulations depending on the water supply. From observations on moulins and a hole which had remained connected to the bed from the previous year it seems likely that at the beginning of the melt season the water pressure at the bed may become as large as or larger than the ice pressure.

On Gornergletscher a record of water pressures has been obtained during the drainage of Gornersee, an ice-dammed lake at the confluence of the two main branches of the glacier. Levels stayed high day and night in the piezometer holes, which were located off to the side of where the main drainage channel was suspected to pass through. The surface drainage pattern was affected over a large area of the glacier. These two observations indicate that during the drainage of the lake some sort of sheet flow must have occurred. The surface velocity of the glacier roughly doubled during that time, but no lifting-up of the ice was observed within the accuracy of the survey. On one occasion on Glacier de Breney the main channel must have been blocked temporarily between an upper area, where the water level was rising simultaneously in three piezometer holes, and an area further down-glacier, where the holes were not affected.

\section{REFERENCE}

Iken, A., and others. [1977.] Deep drilling with a hot water jet, by A. Iken, H. Röthlisberger, and K. Hutter. Zeitschrift für Gletscherkunde und Glazialgeologie, Bd. 12, Ht. 2, 1976, p. 143-56. 


\section{DISCUSSION}

H. Engelhardt: On Blue Glacier only one bore hole which reached the bottom at a subglacial stream responded immediately with a drop in water level. All our other holes but one opened up an interconnecting channel after a few days or several weeks, as indicated by abrupt variations in water level. Did you find on Gornergletscher that the chances to connect a particular bore hole to a major drainage channel are increased as the bore holes are located closer to the channels?

H. Röthlisberger: This question is hard to answer since we can only guess where the channels are located, but as a rule we did find a faster connection to the drainage channels the closer we drilled to existing moulins. Nearer the snout, however, where more water flows at the bed, we obtained connections within one or two days even where no moulins existed in the neighbourhood.

L. A. Lliboutry: We must be careful when speaking of connection or no connection, because the two cases are not clear cut. There may be connection for a discharge of a few centimetres per year of bottom melting, and no connection for a large amount of water coming from surface melting.

G. DE Q. Robin: Is there any evidence that time for connection of bore hole to the main subglacial drainage is a function of thickness of ice, and hence of water-pressure differential at the bottom of the bore hole.

RöTHLisBerger: We had expected that at greater depth it should become easier to establish the connection to the main drainage, but our deepest hole so far did not drain at $330 \mathrm{~m}$ depth (some $50 \mathrm{~m}$ above the bed), even after blasting. Some shallow holes, on the contrary, did drain. We have not yet drilled enough bore holes really to give a final answer to your question.

\section{THE UPLIFT OF UNTERAARGLETSGHER AT THE BEGINNING OF THE MELT SEASON-A CONSEQUENCE OF WATER STORAGE AT THE BED?}

By A. IKen,
(Versuchsanstalt für Wasserbau, Hydrologie und Glaziologie an der Eidgenössischen Technischen Hochschule Zürich, CH-8og2 Zürich, Switzerland)

A. Flotron, (Ingenieurbüro Flotron, Bahnhofstrasse, $\mathrm{CH}-3860$ Meiringen, Switzerland)

W. Haeberli, and H. Röthlisberger

(Versuchsanstalt für Wasserbau, Hydrologie und Glaziologie an der Eidgenössischen Technischen Hochschule Zürich, CH-8og2 Zürich, Switzerland)

Abstract. The results of systematic movement studies carried out by means of an automatic camera on the Unteraargletscher since I969 (Flotron, I973) are discussed together with more recent findings from theodolite measurements made at shorter intervals and over a longer section of the glacier.

In addition to the typical spring/early-summer maximum of velocity known from other glaciers, an upward movement of up to $0.6 \mathrm{~m}$ has been recorded at the beginning of the melt 